\title{
Abundance, distribution and size structure of Diadema antillarum (Echinodermata: Diadematidae) in South Eastern Cuban coral reefs
}

\author{
F. Martín Blanco ${ }^{1,2}$, G. González Sansón ${ }^{2}$, F. Pina Amargós ${ }^{1}$ \& L. Clero Alonso ${ }^{1,2}$ \\ 1. Centro de Investigaciones de Ecosistemas Costeros, Ministerio de Ciencia, Tecnología y Medio Ambiente. Cayo \\ Coco, Morón, Ciego de Ávila, CP 69400, Cuba; felix.martin79@gmail.com, fabian@ciec.fica.inf.cu, \\ 1clero@yahoo.es \\ 2. Centro de Investigaciones Marinas, Universidad de La Habana. Calle 16, \#114 e/ 1ra y 3ra, Miramar, Playa, Ciudad \\ de La Habana, CP. 11300, Cuba; gaspargonzalez2001@yahoo.es
}

Recibido 20-VII-2009. Corregido 05-X-2009. Aceptado 01-XI-2009.

\begin{abstract}
The 1983-1984 mass mortality event of Diadema antillarum affected more than 93\% of the total Caribbean population. Although there are no records about the status of Diadema populations before and after die-off on Cuban reefs, anecdotal information suggests that populations were struck. We analyzed spatial variation in the abundance and size structure of D. antillarum in 22 reefs sites in Jardines de la Reina, from June 2004 to September 2005. Counts of Diadema were performed in five 30x2m transects at each sampling site and sampling time, and test diameters were measured in September 2005 at the same fore reefs. Abundances were higher at reef crests (mean densities $0.08-2.18$ ind. $/ \mathrm{m}^{2}$ ), while reef slope populations reached a maximum site level of 0.13 ind.$/ \mathrm{m}^{2}$ at only one site and showed values up to three orders of magnitude lower than those from reef crests. Highest abundance occurred at the west margin of major channels between keys where larval recruitment seems to be favored by local oceanographic features and facilitated by the abundance of Echinometra lucunter. The size frequency distribution of $D$. antillarum indicates that recruitment began to be noticeable three years before September 2005, suggesting these populations were depleted in the past and they are recovering now. Rev. Biol. Trop. 58 (2): 663-676. Epub 2010 June 02.
\end{abstract}

Keywords: Diadema antillarum, sea urchin recovery, population density, size structure, Jardines de la Reina, Cuba.

The 1983-1984 mass mortality of Diadema antillarum (Philippi 1845) in the Caribbean produced several ill effects on many coral reefs in the region. Beginning in Panama, in January 1983, the mortality spread throughout the area following the course of prevailing surface currents (Lessios et al. 1984). Due to an unidentified pathogen, Diadema populations were depleted by more than $93 \%$ failing to recover in almost the two subsequent decades (Lessios et al. 1984, Lessios 1988, 1995, 2005). It was not until the beginning of the 2000 's, with the exception of Barbados where populations recovered up to $57 \%$ of pre-mortality levels (Hunte \& Younglao 1988), that noticeable increases in population densities were reported for the first time in Jamaica (Aronson \& Precht 2000, Edmunds \& Carpenter 2001, Moses \& Bonem 2001) and St. Croix (Miller et al. 2003); events that were followed by a series of subsequent recovery reports in Costa Rica (Alvarado et al. 2004, Fonseca et al. 2006, Myhre \& AcevedoGutiérrez 2007), Puerto Rico (Weil et al. 2005), Jamaica, St. Croix, Barbados, Grenada, Bonaire, Belize (Carpenter \& Edmunds 2006), Curaçao (Debrot \& Nagelkerken 2006), Dominica (Steiner \& Williams 2006) and Yucatan (Jordán-Garza et al. 2008).

In Cuba there are no records about the status of Diadema populations before die-off 
[only one paper about methodological aspects was published, Herrera-Moreno et al. (1981)], nor scientific reports documenting the mortality. However, anecdotal information indicates that Diadema abundances decreased considerably around Cuban reefs at the beginning of the 1980's (Alcolado P.M., pers. comm.). As Lessios (2005) pointed out, pre-mortality density data are essential for determining the degree of subsequent recovery, so any apparent recovery of Diadema populations in Cuban reefs should be discussed with caution. In spite of the importance of Diadema as a keystone species in structuring coral reefs, available information about its current status in Cuban reefs is scarce. Except for local density data, no other aspects of the species ecology have been reported. The most complete data come from The Atlantic and Gulf Rapid Reef Assessment (AGRRA) surveys carried out at 199 reef sites around the Cuban archipelago from 1999 to 2003. Using that information, Alcolado et al. (unpublished data) only reported punctual values of Diadema densities showing that there is still little evidence of a country-wide recovery. Williams \& Polunin (2001) and Guardia et al. (2004a, b, 2006), reported zero or near zero densities in Cuban Western reefs, while the most recent data correspond to surveys in the North coast of Havana where Caballero et al. (2006) reported mean densities of $D$. antillarum in collection sites monitored by scientists from the National Aquarium of Cuba.

The present report analyzes spatial variation in densities and size structure (for the first time) of $D$. antillarum within and adjacent to a marine reserve in Jardines de la Reina Archipelago, Cuba, compares density data from local and country wide assessments and discusses the possible factors that influence sea urchin abundance and distribution in the study area. Surveys were part of a broader research to evaluate the effectiveness of the marine reserve on reef fish assemblages.

\section{MATERIALS AND METHODS}

Study area: The Archipelago of Jardines de la Reina is one of the four main groups of islands around Cuba and the best conserved of all. Stretching approximately $360 \mathrm{~km}$, it is formed by 661 keys, which are located in the south-central part of the Cuban shelf between the Gulf of Ana María and the Gulf of Guacanayabo (Fig. 1). The archipelago has three groups of keys, the most important one is that of "Las Doce Leguas" (The Twelve Leagues) located in its westernmost end. In 1996 two thirds of the archipelago (about $950 \mathrm{~km}^{2}$ ) were declared as Zone Under Special Regime of Use and Protection (equivalent to the internationally known Marine Reserves, and so termed in this paper) by the Ministry of Fisheries and currently pending approval as a National Park by the Cuban Government. This is the largest of the Caribbean Marine Reserves and its coral reefs are among the best preserved in the region (Appeldoorn \& Lindeman 2003). Several patch reefs exist to the north of the keys while the most important and well developed fringing reefs are found in the southern side, where the most conspicuous are reefs crests (1-3m depth) and reefs slopes (12-15m the shallow reef slope and $20-30 \mathrm{~m}$ the deep reef slope).

Survey methodology: Surveys were conducted in the southern fore reefs of Jardines de la Reina, in the group of keys of "Las Doce Leguas", in June 2004, April 2005 and September 2005. Counts of D. antillarum were performed at each sampling time in five $30 \times 2 \mathrm{~m}$ transects located parallel to 12 reefs crests (specifically in the front part) and 22 shallow reefs slopes, all distributed along 22 sampling sites (Table 1, Fig. 1). Diadema test diameters were measured in September 2005 at the same fore reefs; maximum test diameter of individuals encountered in transects was measured to the nearest millimeter with long-jawed calipers. 


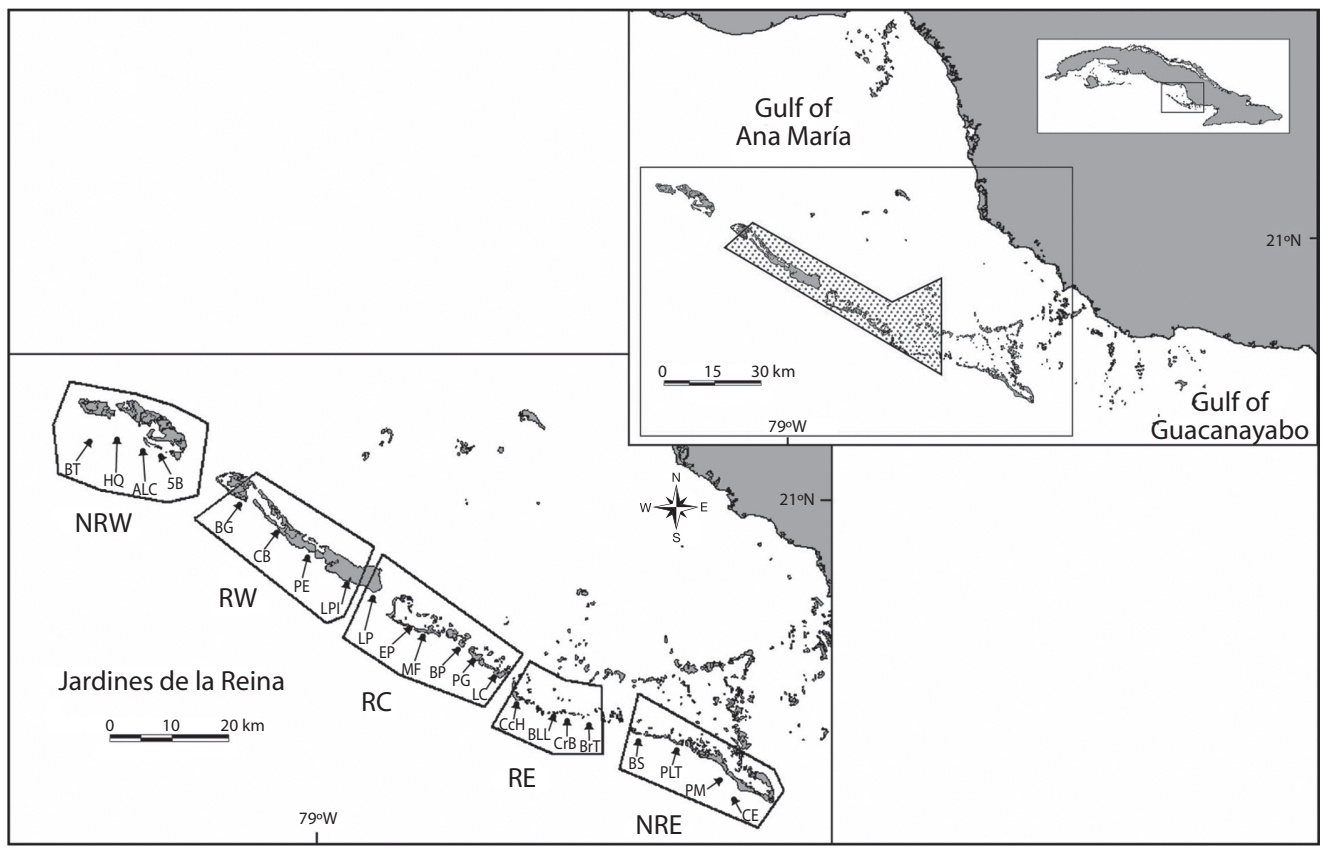

Fig. 1. Study zones and sampling sites in Jardines de la Reina, Cuba. Doted area represents the Zone Under Special Regime of Use and Protection. NRW=Non-reserve Western Zone, RW=Reserve Western Zone, RC=Reserve Central Zone, $\mathrm{RE}=$ Reserve Eastern Zone, NRE=Non-reserve Eastern Zone, $\mathrm{BT}=$ Bretón, $\mathrm{HQ}=$ Horqueta, $\mathrm{ALC}=\mathrm{Alcatraz}, 5 \mathrm{~B}=\mathrm{Cinco} \mathrm{Balas}$, $\mathrm{BG}=$ Boca de Guano, $\mathrm{CB}=$ Caseta Blanca, $\mathrm{PE}=\mathrm{Punta}$ Escondida, $\mathrm{LPI}=\mathrm{Los}$ Pinos, $\mathrm{LP}=\mathrm{La}$ Puntica, EP=El Partido, MF=Mari Flores, $\mathrm{BP}=\mathrm{Boca}$ de Piedra, $\mathrm{PG}=$ Piedra Grande, $\mathrm{LC}=\mathrm{Las}$ Cruces, $\mathrm{CcH}=$ Cachiboca, $\mathrm{BLL}=\mathrm{Ballena}, \mathrm{CrB}=\mathrm{Carabinero}$, BrT=Bártolo, $\mathrm{BS}=$ Boca Seca, $\mathrm{PLT}=$ Peralta, $\mathrm{PM}=$ Punta Macao, $\mathrm{CE}=$ Cabeza del Este.

Fig. 1. Zonas de estudio y sitios de muestreo en Jardines de la Reina, Cuba. El área punteada representa la Zona Bajo Régimen Especial de Uso y Protección. NRW=Zona No Reserva Oeste, RW=Zona Reserva Oeste, RC=Zona Reserva Centro, $\mathrm{RE}=$ Zona Reserva Este, $\mathrm{NRE}=$ Zona No Reserva Este, $\mathrm{BT}=$ Bretón, $\mathrm{HQ}=$ Horqueta, $\mathrm{ALC}=\mathrm{Alcatraz}, 5 \mathrm{~B}=\mathrm{Cinco} \mathrm{Balas}$, $\mathrm{BG}=$ Boca de Guano, $\mathrm{CB}=$ Caseta Blanca, $\mathrm{PE}=$ Punta Escondida, $\mathrm{LPI}=\mathrm{Los}$ Pinos, $\mathrm{LP}=\mathrm{La}$ Puntica, $\mathrm{EP}=\mathrm{E} 1 \mathrm{Partido}, \mathrm{MF}=\mathrm{Mari}$ Flores, $\mathrm{BP}=$ Boca de Piedra, $\mathrm{PG}=$ Piedra Grande, $\mathrm{LC}=$ Las Cruces, $\mathrm{CcH}=$ Cachiboca, $\mathrm{BLL}=\mathrm{Ballena}, \mathrm{CrB}=\mathrm{Carabinero}$, BrT=Bártolo, $\mathrm{BS}=$ Boca Seca, $\mathrm{PLT}=$ Peralta, $\mathrm{PM}=$ Punta Macao, $\mathrm{CE}=$ Cabeza del Este.

Bottom rugosity was estimated at sites surveyed in June 2004 by means of the tape contour method. Measures $(n=5)$ were made by laying a $10 \mathrm{~m}$ long PVC tape over the substrate, positioned to follow the contours of the reef as closely as possible and then measuring the distance between the start and end of the "contour". Rugosity was calculated as the ratio of "contour" length to tape length. Complementary information, based on the results of Pina-Amargós et al. (2008) who analyzed habitat complexity at the same sites in April 2005, September, 2005 and December 2005 by means of a semi-quantitative scale, were used for discussion.

Data collected from sites were grouped in pre-determined zones, three within the marine reserve and two (westward and eastward) adjacent to the marine reserve (Fig. 1). The zone classifying criteria was based on the existing different degrees of protection in the Marine Reserve regarding that protection decreases from Reserve Central Zone (RC), Reserve Western Zone (RW), Reserve Eastern Zone (RE) to Non-reserve Western Zone (NRW) and Non-reserve Eastern Zone (NRE) which 
TABLE 1

Sampling sites in Jardines de la Reina, Cuba

CUADRO 1

Sitios de muestreo en Jardines de la Reina, Cuba

Site

Bretón (BT)

Horqueta (HQ)

Alcatraz (ALC)

Cinco Balas (5B)

Boca de Guano(BG)

Caseta Blanca (CB)

Punta Escondida (PE)

Los Pinos (LPI)

La Puntica (LP)

El Partido (EP)

Mari Flores (MF)

Boca de Piedra (BP)

Bretón (BT)

Horqueta (HQ)

Alcatraz (ALC)

Cinco Balas (5B)

Boca de Guano(BG)

Caseta Blanca (CB)

Punta Escondida (PE)

Los Pinos (LPI)

La Puntica (LP)

El Partido (EP)

Mari Flores (MF)

Boca de Piedra (BP)

Piedra Grande (PG)

Las Cruces (LC)

Cachiboca $(\mathrm{CcH})$

Ballena (BLL)

Carabinero (CrB)

Bártolo (BrT)

Boca Seca (BS)

Peralta (PLT)

Punta Macao (PM)

Cabeza del Este (CE)
Latitude

$21^{\circ} 04^{\prime} 03^{\prime \prime}$

$21^{\circ} 04^{\prime} 16^{\prime \prime}$

$21^{\circ} 02^{\prime} 83^{\prime \prime}$

$21^{\circ} 01^{\prime} 51^{\prime \prime}$

$20^{\circ} 58^{\prime} 00^{\prime \prime}$

$20^{\circ} 55^{\prime} 48^{\prime \prime}$

$20^{\circ} 51^{\prime} 26^{\prime \prime}$

$20^{\circ} 50$ ' $76^{\prime \prime}$

$20^{\circ} 49^{\prime} 55^{\prime \prime}$

$78^{\circ} 55^{\prime} 01^{\prime \prime}$

$20^{\circ} 46^{\prime} 30^{\prime \prime}$

$20^{\circ} 45^{\prime} 72^{\prime \prime}$

$21^{\circ} 03^{\prime} 52^{\prime \prime}$

$21^{\circ} 04^{\prime} 02^{\prime \prime}$

$21^{\circ} 02$ ' $54^{\prime \prime}$

$21^{\circ} 01^{\prime} 45^{\prime \prime}$

$20^{\circ} 57^{\prime} 49^{\prime \prime}$

$20^{\circ} 55^{\prime} 38^{\prime \prime}$

$20^{\circ} 51^{\prime} 44^{\prime \prime}$

$20^{\circ} 50^{\prime} 61^{\prime \prime}$

$78^{\circ} 59^{\prime} 05^{\prime \prime}$

$78^{\circ} 55^{\prime} 11^{\prime \prime}$

$20^{\circ} 46^{\prime} 14^{\prime \prime}$

$20^{\circ} 45^{\prime} 70^{\prime \prime}$

$20^{\circ} 44^{\prime} 08^{\prime \prime}$

$20^{\circ} 42$ ' 33"

$20^{\circ} 40^{\prime} 08^{\prime \prime}$

$20^{\circ} 38^{\prime} 56^{\prime \prime}$

$20^{\circ} 38$ '39"

$20^{\circ} 38^{\prime} 08^{\prime \prime}$

$20^{\circ} 36^{\prime} 46^{\prime \prime}$

$20^{\circ} 35^{\prime} 56^{\prime \prime}$

$20^{\circ} 33^{\prime} 11^{\prime \prime}$

$20^{\circ} 31^{\prime} 30^{\prime \prime}$
Reef crests

\begin{tabular}{|c|c|}
\hline Longitude & Depth (m) \\
\hline $79^{\circ} 25^{\prime} 29^{\prime \prime}$ & $2-3$ \\
\hline $79^{\circ} 23^{\prime} 57^{\prime \prime}$ & $2-3$ \\
\hline $79^{\circ} 20^{\prime} 28^{\prime \prime}$ & $2-3$ \\
\hline $79^{\circ} 17^{\prime} 44^{\prime \prime}$ & $2-3$ \\
\hline $79^{\circ} 10^{\prime} 47^{\prime \prime}$ & $2-3$ \\
\hline $79^{\circ} 08^{\prime} 06^{\prime \prime}$ & $2-3$ \\
\hline $79^{\circ} 02^{\prime} 53^{\prime \prime}$ & $2-3$ \\
\hline $79^{\circ} 00^{\prime} 78^{\prime \prime}$ & $2-3$ \\
\hline $78^{\circ} 58^{\prime} 52^{\prime \prime}$ & $2-3$ \\
\hline $20^{\circ} 46^{\prime} 47^{\prime \prime}$ & $2-3$ \\
\hline $78^{\circ} 53^{\prime} 61^{\prime \prime}$ & $2-3$ \\
\hline $78^{\circ} 50^{\prime} 65^{\prime \prime}$ & $2-3$ \\
\hline \multicolumn{2}{|l|}{ Reef slopes } \\
\hline $79^{\circ} 26^{\prime} 12^{\prime \prime}$ & $12-15$ \\
\hline $79^{\circ} 23^{\prime} 36^{\prime \prime}$ & $12-15$ \\
\hline $79^{\circ} 20^{\prime} 24^{\prime \prime}$ & $12-15$ \\
\hline $79^{\circ} 17^{\prime} 34^{\prime \prime}$ & $12-15$ \\
\hline $79^{\circ} 10^{\prime} 45^{\prime \prime}$ & $12-15$ \\
\hline $79^{\circ} 07^{\prime} 58^{\prime \prime}$ & $12-15$ \\
\hline $79^{\circ} 03^{\prime} 30^{\prime \prime}$ & $12-15$ \\
\hline $79^{\circ} 00^{\prime} 71^{\prime \prime}$ & $12-15$ \\
\hline $20^{\circ} 49^{\prime} 50^{\prime \prime}$ & $12-15$ \\
\hline $20^{\circ} 46^{\prime} 35^{\prime \prime}$ & $12-15$ \\
\hline $78^{\circ} 53^{\prime} 48^{\prime \prime}$ & $12-15$ \\
\hline $78^{\circ} 50^{\prime} 62^{\prime \prime}$ & $12-15$ \\
\hline $78^{\circ} 48^{\prime} 59^{\prime \prime}$ & $12-15$ \\
\hline $78^{\circ} 46^{\prime} 59^{\prime \prime}$ & $12-15$ \\
\hline $78^{\circ} 44^{\prime} 45^{\prime \prime}$ & $12-15$ \\
\hline $78^{\circ} 41^{\prime} 09^{\prime \prime}$ & $12-15$ \\
\hline $78^{\circ} 39^{\prime} 51^{\prime \prime}$ & $12-15$ \\
\hline $78^{\circ} 37^{\prime} 41^{\prime \prime}$ & $12-15$ \\
\hline $78^{\circ} 32^{\prime} 57^{\prime \prime}$ & $12-15$ \\
\hline $78^{\circ} 29^{\prime} 10^{\prime \prime}$ & $12-15$ \\
\hline $78^{\circ} 24^{\prime} 57^{\prime \prime}$ & $12-15$ \\
\hline $78^{\circ} 23^{\prime} 38^{\prime \prime}$ & $12-15$ \\
\hline
\end{tabular}


show a higher human activity. That information was obtained previously to the design of this study which is part of a broader research (Pina-Amargós 2008) carried out to evaluate the effectiveness of the Marine Reserve. Densities and test diameters of $D$. antillarum recorded from reef crests were compared among zones at each sampling time using a one way ANOVA and the Student-Newman-Keuls test for posthoc comparisons. Density data were transformed using the forth root transformation as suggested by the log-mean vs. log-variance relationship (Taylor's Law) for conformity to the assumptions of normality and variance homogeneity. No statistical analyses were performed with densities recorded from reef slopes to prevent erroneous results caused by a high proportion of zero values. Because of obvious differences in Diadema densities between habitats, statistical comparison was unnecessary.

The size frequency distributions of Diadema pooled across all sites and pooled across sites of different zones at reef crests were determined and the latter were compared among zones with chi-square tests. Pearson's correlation coefficient was used to determine whether mean test diameters were correlated with mean densities of Diadema at reefs crests and whether there was a relationship between the mean densities of Diadema and the mean densities of Echinometra lucunter (Linnaeus) recorded at the same sites in June 2004, prior to the beginning of Diadema counts.

A one way ANOVA was also used to test for significant differences among zones in habitat structural complexity and the StudentNewman-Keuls test for post-hoc comparisons. Pearson's correlation coefficient was also used to test for the influence of substrate rugosity on Diadema population densities across sites at both the reef crest and reef slope habitats (Power calculations were performed using GPOWER 2.0). All statistical analyses were performed using STATISTICA 6.0.

\section{RESULTS}

Urchin abundance and habitat structural complexity: Abundances of $D$. antillarum were lowest at reef slopes during the study. In June 2004, urchins were found at six of nine sites surveyed (67\%), while in the next year Diadema was present at only $58 \%$ (of 19 sites) and 55\% (of 20 sites) in April and September respectively. Mean population densities recorded at this habitat ranged from $0.010-0.070$ ind. $/ \mathrm{m}^{2}$ in June 2004, while the lowest local value in April 2005 was 0.003 ind. $/ \mathrm{m}^{2}$ (Table 2). The maximum site level density (0.133 ind. $/ \mathrm{m}^{2}$ ) occurred in April 2005, but there was only one site showing this value. Abundances remained low in September 2005 ranging from $0.003-0.083$ ind.$/ \mathrm{m}^{2}$ with only three sites showing densities higher than 0.020 ind. $/ \mathrm{m}^{2}$ (Table 2).

In contrast to reef slopes, mean densities of Diadema at reef crests were up to three orders of magnitude higher, showing local values from 0.013 ind. $/ \mathrm{m}^{2}$ at $\mathbf{B T}$ to 1.016 ind. $/ \mathrm{m}^{2}$ at $\mathbf{L P}$ in June 2004 while in April 2005 densities ranged from $0.013-1.553$ ind. $/ \mathrm{m}^{2}$ with extreme values at same sites. The maximum site level density was recorded in September 2005, at PE, population densities were higher than 1 ind. $/ \mathrm{m}^{2}$ at 42 $\%$ of the reef crests surveyed (Table 2 ).

Mean population densities of $D$. antillarum varied significantly among zones at reef crests at each sampling time $\left(\mathrm{F}_{(1,28)}=36.434\right.$, $\mathrm{p}<0.01$, in June 2004; $\mathrm{F}_{(2,46)}=36.522, \mathrm{p}<0.01$, in April 2005; $\mathrm{F}_{(2,57)}=45.409, \mathrm{p}<0.01$, in September 2005; Fig. 2) and followed the same spatial pattern of variation as mean densities across sites $\left(\mathrm{F}_{(5,24)}=12.426, \mathrm{p}<0.01\right.$, in June 2004, $\mathrm{F}_{(9,39)}=10.155, \mathrm{p}<0.01$, in April 2005 and $\mathrm{F}_{(11,48)}=17.596, \mathrm{p}<0.01$, in September 2005; data not shown). Mean abundances were higher at zones RC (0.741 ind. $\left./ \mathrm{m}^{2}\right)$ and RW (1.465 ind. $\left./ \mathrm{m}^{2}\right)$ in June 2004 and September 2005 respectively while in April 2005 there were 
TABLE 2

Mean densities (ind./m2 \pm SE) of Diadema antillarum at fore reef sites in Jardines de la Reina (2004-2005)

CUADRO 2

Densidades promedio (ind./m2 EE ) de Diadema antillarum en los arrecifes de Jardines de la Reina (2004-2005)

\begin{tabular}{|c|c|c|c|c|c|c|}
\hline \multirow{2}{*}{ Site } & \multicolumn{2}{|c|}{ June 2004} & \multicolumn{2}{|c|}{ April 2005} & \multicolumn{2}{|c|}{ September 2005} \\
\hline & R. Slope & R. Crest & R. Slope & R. Crest & R. Slope & R. Crest \\
\hline BT & 0 & $0.013 \pm 0.009$ & 0 & $0.013 \pm 0.013$ & 0 & 0 \\
\hline HQ & 0 & $0.087 \pm 0.037$ & 0 & $0.197 \pm 0.078$ & 0 & $0.077 \pm 0.049$ \\
\hline ALC & N/A & N/A & $0.003 \pm 0.003$ & $0.020 \pm 0.010$ & $0.020 \pm 0.012$ & $0.043 \pm 0.012$ \\
\hline $5 \mathrm{~B}$ & $0.010 \pm 0.007$ & $0.117 \pm 0.022$ & 0 & $0.053 \pm 0.033$ & $0.003 \pm 0.003$ & $0.077 \pm 0.016$ \\
\hline BG & N/A & N/A & N/A & $0.870 \pm 0.208$ & 0 & $1.327 \pm 0.441$ \\
\hline $\mathrm{CB}$ & N/A & N/A & $0.020 \pm 0.013$ & $0.757 \pm 0.230$ & 0 & $1.220 \pm 0.543$ \\
\hline PE & N/A & N/A & 0 & $1.297 \pm 0.430$ & 0 & $2.183 \pm 0.240^{*}$ \\
\hline LPI & N/A & N/A & $0.020 \pm 0.012$ & N/A & 0 & $1.130 \pm 0.218$ \\
\hline LP & $0.070 \pm 0.037$ & $1.013 \pm 0.440$ & N/A & $1.553 \pm 0.478$ & N/A & $1.137 \pm 0.189$ \\
\hline EP & N/A & N/A & 0 & N/A & 0 & $0.103 \pm 0.033$ \\
\hline MF & $0.017 \pm 0.013$ & $0.410 \pm 0.052$ & 0 & $0.713 \pm 0.240$ & 0 & $0.597 \pm 0.155$ \\
\hline BP & 0 & $0.797 \pm 0.195$ & N/A & $1.010 \pm 0.301$ & N/A & $0.740 \pm 0.273$ \\
\hline PG & N/A & $\mathrm{N} / \mathrm{E}$ & $0.003 \pm 0.003$ & $\mathrm{~N} / \mathrm{E}$ & $0.003 \pm 0.003$ & $\mathrm{~N} / \mathrm{E}$ \\
\hline LC & N/A & $\mathrm{N} / \mathrm{E}$ & $0.017 \pm 0.007$ & $\mathrm{~N} / \mathrm{E}$ & $0.003 \pm 0.003$ & $\mathrm{~N} / \mathrm{E}$ \\
\hline $\mathrm{CCH}$ & N/A & $\mathrm{N} / \mathrm{E}$ & $0.057 \pm 0.016$ & $\mathrm{~N} / \mathrm{E}$ & $0.083 \pm 0.029$ & $\mathrm{~N} / \mathrm{E}$ \\
\hline BLL & N/A & $\mathrm{N} / \mathrm{E}$ & $0.003 \pm 0.003$ & $\mathrm{~N} / \mathrm{E}$ & $0.067 \pm 0.033$ & $\mathrm{~N} / \mathrm{E}$ \\
\hline CRB & N/A & $\mathrm{N} / \mathrm{E}$ & $0.133 \pm 0.059 *$ & $\mathrm{~N} / \mathrm{E}$ & $0.003 \pm 0.003$ & $\mathrm{~N} / \mathrm{E}$ \\
\hline BRT & N/A & $\mathrm{N} / \mathrm{E}$ & $0.020 \pm 0.013$ & $\mathrm{~N} / \mathrm{E}$ & $0.003 \pm 0.003$ & $\mathrm{~N} / \mathrm{E}$ \\
\hline BS & $0.013 \pm 0.006$ & $\mathrm{~N} / \mathrm{E}$ & 0 & $\mathrm{~N} / \mathrm{E}$ & $0.003 \pm 0.003$ & $\mathrm{~N} / \mathrm{E}$ \\
\hline PLT & $0.013 \pm 0.008$ & $\mathrm{~N} / \mathrm{E}$ & $0.003 \pm 0.003$ & $\mathrm{~N} / \mathrm{E}$ & 0 & $\mathrm{~N} / \mathrm{E}$ \\
\hline PM & $0.050 \pm 0.021$ & $\mathrm{~N} / \mathrm{E}$ & $0.007 \pm 0.007$ & $\mathrm{~N} / \mathrm{E}$ & $0.027 \pm 0.015$ & $\mathrm{~N} / \mathrm{E}$ \\
\hline $\mathrm{CE}$ & N/A & $\mathrm{N} / \mathrm{E}$ & 0 & $\mathrm{~N} / \mathrm{E}$ & $0.020 \pm 0.013$ & $\mathrm{~N} / \mathrm{E}$ \\
\hline
\end{tabular}

$\mathrm{SE}=$ Standard error; R. Slope=Reef Slope; R. Crest=Reef Crest; N/A=Data not available; N/E=Habitat does not exist; *=Maximum site level density during the study at corresponding habitat.

no significant differences in densities recorded from these zones which were indeed significantly higher than density recorded from NRW zone, where lowest values occurred during the study (Fig. 2).

Mean densities of Diadema at reef crests were correlated with mean densities of $E$. lucunter showing a significant positive relationship in June 2004 (Pearson's correlation, $\mathrm{r}=0.85, \mathrm{p}=0.03, \mathrm{n}=6$ ).

Bottom rugosity in June 2004 did not vary significantly among zones neither at reef slopes nor at reef crests $\left(\mathrm{F}_{(1,43)}=0.20, \mathrm{p}>0.05\right.$, Power $=1 ; \mathrm{F}_{(1,28)}=0.34, \mathrm{p}>0.05$ Power $=1$ respectively). Correlation between mean values of substrate rugosity and mean population densities of $D$. antillarum were not significant at reef crest $(r=0.74, p=0.09, n=6$, Power $=0.81)$.

Size structure: Mean test diameter of D. antillarum in September 2005 was $57.04 \pm 3.56 \mathrm{~mm}$ at reef slope and $56.85 \pm 0.68$ at reef crest (Table 3 ). Due to the low number of measurements at reef slopes $(n=24)$ no statistical analyzes were performed. On the other hand, mean sizes at reef crests were significantly different among zones $\left(\mathrm{F}_{(2,566}=33.914\right.$, $\mathrm{p}<0.01$; Fig. 3) and showed a significant positive relationship with mean population density (Pearson's correlation, $\mathrm{r}=0.94, \mathrm{p}<0.05$; Fig. 4). 

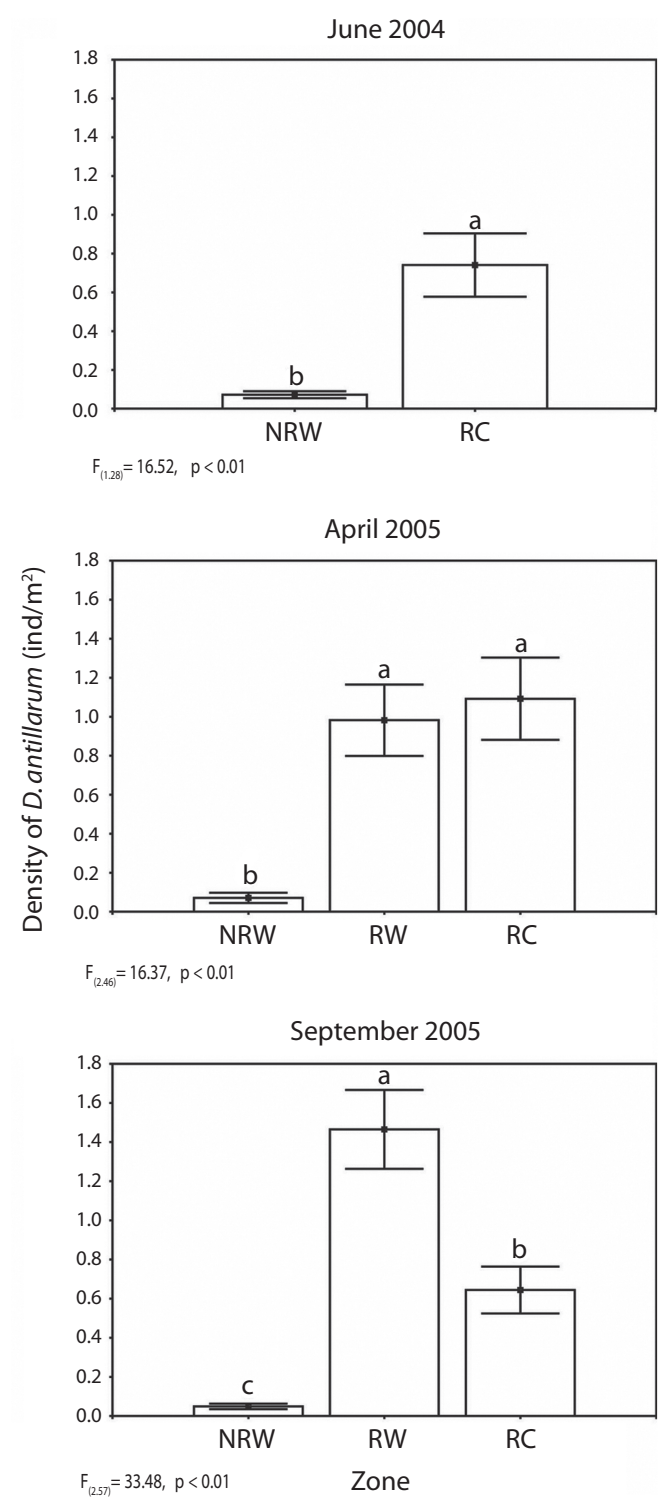

Fig. 2. Mean population densities (SE) of Diadema antillarum at reef crests across zones in Jardines de la Reina at each sampling time. Different letters indicate significant differences.

Fig. 2. Densidades promedio (EE) de Diadema antillarum por zona en las crestas arrecifales muestreadas en Jardines de la Reina en cada mes de muestreo. Las letras diferentes indican diferencias significativas.
TABLE 3

Mean sizes of Diadema antillarum at fore reef sites in Jardines de la Reina (September 2005)

CUADRO 3

Tallas promedio de Diadema antillarum en los arrecifes de Jardines de la Reina (Septiembre 2005)

Site

HQ

Mean size $(\mathrm{mm}) \pm \mathrm{SE} \quad \mathrm{N}$

Reef Crest

$41.22 \pm 2.84 \quad 32$

$5 \mathrm{~B}$

$39.20 \pm 3.53 \quad 20$

BG

$62.91 \pm 1.77$

64

CB

$57.78 \pm 2.16$

$58.82 \pm 1.59$

86

PE

$58.81 \pm 1.65$

74

LPI

$60.53 \pm 2.06$

57

LP

$47.75 \pm 2.54$

76

EP

$56.58 \pm 1.14$

16

MF

$57.28 \pm 2.07$

94

BP

$56.85 \pm 0.68$

50

All sites

Reef Slope

5B

17.00

$60.67 \pm 6.55$

$63.12 \pm 4.47$

$43.25 \pm 9.45$

$65.25 \pm 6.22$

49.00

$57.04 \pm 3.56$

All sites

$57.04 \pm 3.56$

$\mathrm{N}=$ number of urchins measured in five transects; $\mathrm{SE}=$ standard error.

Urchins from zones RW and $\mathbf{R C}$ were similar in size and larger than urchins from zone NRW (Fig. 3).

Size frequency distribution of Diade$m a$ at reef crests varied significantly among zones. The NRW size distribution was different from both the RW distribution (chisquare $=298.81, \mathrm{p}<0.01)$ and the $\mathbf{R C}$ distribution (chi-square=191.65, $\mathrm{p}<0.01$ ) which did not differ significantly from one another (chisquare $=7.39, \mathrm{p}>0.05$ ) and were dominated by $51-70 \mathrm{~mm}$ urchins $(52 \%$ at zone RW and $49 \%$ 


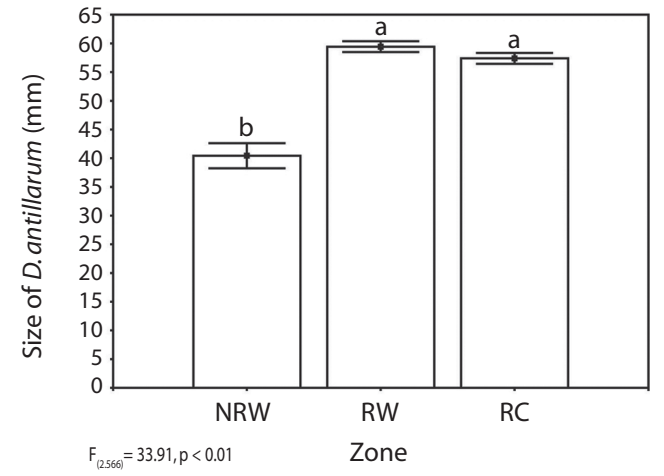

Fig. 3 Mean sizes (SE) of Diadema antillarum at reef crests across zones in Jardines de la Reina during September 2005. Different letters indicate significant differences.

Fig. 3. Tallas promedio (EE) de Diadema antillarum por zona en las crestas arrecifales de Jardines de la Reina en Septiembre de 2005. Las letras diferentes indican diferencias significativas.

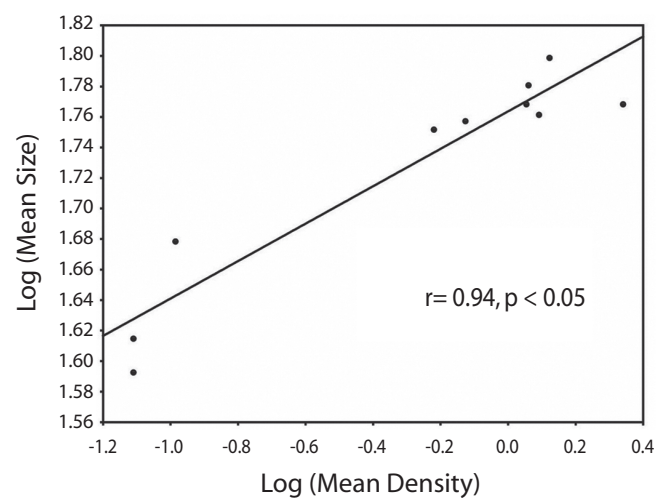

Fig. 4. Positive correlation between mean size and mean density of Diadema antillarum across sites at reef crests in Jardines de la Reina during September 2005. Data is presented as $\log ($ mean $)$. Equation of line is: $\log ($ mean size $)=0.1226 \log$ (mean density $)+1.7637$.

Fig. 4. Correlación positiva entre la talla promedio y la densidad promedio de Diadema antillarum por sitios en las crestas arrecifales muestreadas en Jardines de la Reina en Septiembre de 2005. Los datos aparecen representados como el log (media) y la ecuación de la recta es log(talla promedio $)=0.1226 \log ($ densidad promedio $)+1.7637$. at zone RC). In contrast, NRW zone showed a higher proportion of individuals in the smallest cohort $(58 \% \leq 40 \mathrm{~mm})$ particularly in the $31-40 \mathrm{~mm}$ size class $(25 \%)$; mid sizes were also well represented in that zone with $23 \%$ of urchins in the 51-60mm size class (Fig. 5). The size frequency distribution pooled across all sites was dominated by medium-sized to large urchins with $48 \%$ between $51-70 \mathrm{~mm}$ and individuals from small sizes $(\leq 40 \mathrm{~mm})$ were scarce (16\%; Fig. 6).

\section{DISCUSSION}

Populations of $D$. antillarum were restricted to the reef crests (1-3m depth) in the $40 \%$ of surveyed sites in Jardines de la Reina Archipelago. Even when Diadema appeared at reef slopes (12-15m depth) population densities were very low (up to three orders of magnitude lower than reef crests). Because of the lack of scientific records about the status of Diadema before and after the mass mortality, current urchin abundances can not be compared with historical data. However, if we consider premortality values reported by Hughes et al. (1985) and Liddell \& Ohlhorst (1986) at similar depths in the north coast of Jamaica, recent densities in Jardines de la Reina are far below those that could potentially exist at such depths before the mortality.

Similar results have been recently reported for several locations around the Cuban archipelago, suggesting a country wide pattern of low population density at mid depth reefs. Alcolado et al. (unpublished data) recorded very low densities (0.01-0.1 ind. $/ \mathrm{m}^{2}$ ) at reef slopes in Jardines de la Reina (same region of present study but different sampling sites) Eastern Bahía de Cochinos, south-central Cuba $(<0.05$ ind. $/ \mathrm{m}^{2}$ ) and María La Gorda, southwestern end of Cuba $\left(<0.05\right.$ ind. $\left./ \mathrm{m}^{2}\right)$ where Guardia et al. (2004a) found no urchins at similar depths. Diadema was also absent at reef slopes, except 

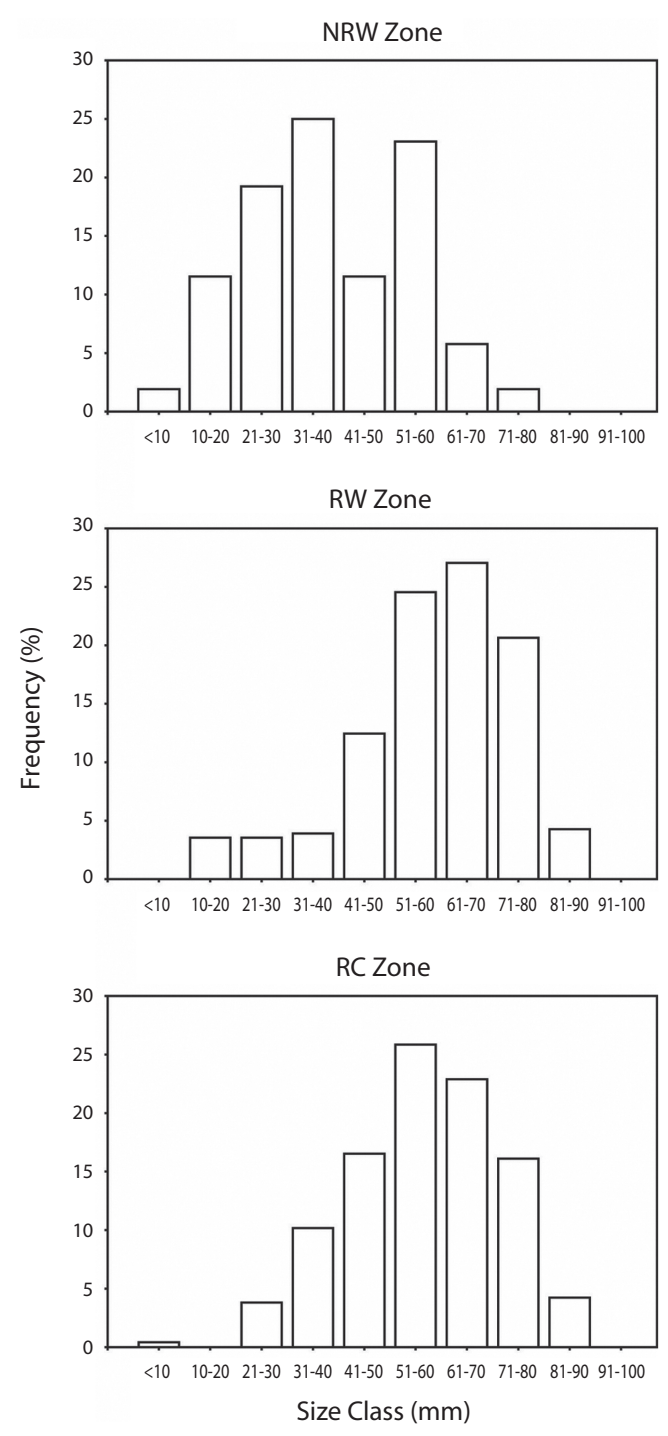

Fig. 5. Size frequency distribution of Diadema antillarum at reef crests at each study zone in Jardines de la Reina during September 2005.

Fig. 5. Distribución de frecuencia de talla de D. antillarum por zonas en las crestas arrecifales muestreadas en Jardines de la Reina en Septiembre de 2005.

in one site $\left(0.01 \mathrm{ind} . / \mathrm{m}^{2}\right)$, in Sabana-Camagüey Archipelago, north-central Cuba (Alcolado et al. unpublished data), and absent at all sampled locations in Punta Francés, southwestern Cuba (Williams \& Polunin 2001, Guardia et

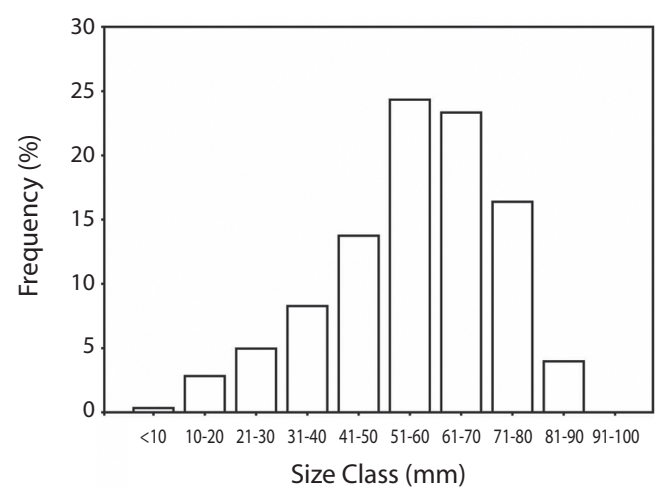

Fig. 6. Size-frequency distribution of Diadema antillarum pooled across all sites in Jardines de la Reina during September 2005.

Fig. 6. Distribución de frecuencia de talla acumulada de $D$. antillarum en todos los sitios muestreados en Jardines de la Reina en Septiembre de 2005.

al. 2004b) and Punta del Este, southwestern Cuba (Williams \& Polunin 2001). In contrast, reef slope populations from the north coast of Havana, where Diadema appears to be more abundant at mid depths, showed higher levels of population density, reaching up to 0.63 ind./ $\mathrm{m}^{2}$ (Alcolado et al. unpublished data).

Data collected from Cuban reef slopes and those of other recent studies in the Caribbean region at similar depths (Haley \& Solandt 2001, Moses \& Bonem 2001 in Jamaica; Williams \& Polunin 2001 in Barbados, Belize, Grand Cayman and Jamaica; Chiappone et al. 2002 in Florida Keys; Lessios 2005 in Panama; Carpenter \& Edmunds 2006 in Jamaica, St. Croix, Grenada, Barbados, Bonaire and Belize; Debrot \& Nagelkerken 2006 in Curaçao) show that western Atlantic mid-depth populations of D. antillarum are still far from recovery, despite simultaneous increases in shallow reef populations observed in Jamaica (Aronson \& Precht 2000, Edmunds \& Carpenter 2001, Haley \& Solandt 2001), St. Croix (Miller et al. 2003) and earlier in Barbados (Hunte \& Younglao 1988) indicated the possible beginning of a full population recovery in the Caribbean. Such a recovery has been recently documented 
in Costa Rica (Alvarado et al. 2004, Myhre \& Acevedo-Gutiérrez 2007), Puerto Rico (Weil et al. 2005) Barbados (Macintyre et al. 2005, Carpenter \& Edmunds 2006), Curaçao (Debrot \& Nagelkerken 2006), Dominica (Steiner \& Williams 2006), Jamaica, St. Croix, Grenada, Bonaire, Belize (Carpenter \& Edmunds 2006), Venezuela (Noriega et al. 2006) and Yucatan (Jordán-Garza et al. 2008).

Results from reef crest populations in Jardines de la Reina (this study) are consistent with those presented by Carpenter \& Edmunds (2006), who reported that dense populations of $D$. antillarum now occur at both local and regional scales in the Caribbean. Mean population densities recorded in Jardines de la Reina shallow reefs by this study are higher than those reported by Alcolado et al. (unpublished data) at similar depths in Eastern Bahía de Cochinos, south-central Cuba $\left(\approx 0.075\right.$ ind. $\left./ \mathrm{m}^{2}\right)$; Gulf of Batabanó, southwestern Cuba $(\approx 0.83$ ind./ $\mathrm{m}^{2}$ ) and Archipelago Sabana-Camagüey, northcentral Cuba $\left(<0.2\right.$ ind. $\left./ \mathrm{m}^{2}\right)$. The maximum site level densities recorded by these authors at the reef crests of "Las Doce Leguas" in Jardines de la Reina were slightly lower $\left(0.93\right.$ ind. $/ \mathrm{m}^{2}$ in Caballones Centro and 0.94 ind. $/ \mathrm{m}^{2}$ in Cayo Grande Este) than present densities at neighbor reefs. Because of different sites and sampling methodology, no statistical comparisons were possible. Only one site studied by Alcolado et al. (Canal de las Mulatas) located westward, out of the keys of "Las Doce Leguas" and closer to mainland showed a comparatively high density of Diadema (2.11 ind. $\left./ \mathrm{m}^{2}\right)$, similar to the highest density recorded at present study $\left(2.18\right.$ ind. $\left./ \mathrm{m}^{2}\right)$.

On the other hand, abundances of $D$. antillarum recorded at Jardines de la Reina (this study) are lower than those recorded by Alcolado et al. (unpublished data) at Playa Franceses, north coast of Havana, which represents the highest value reported for Cuban shallow reefs until now $\left(8.1\right.$ ind. $\left./ \mathrm{m}^{2}\right)$. The increase in more than 5 ind. $/ \mathrm{m}^{2}$ at this site between 1997 and 2003 indicates successful recruitment and population persistence along time. However, due to the sampling method used at this site
( $1 \mathrm{~m}^{2}$ quadrants) or maybe a bias in the way the quadrants were placed, density values reported by these authors at this site could be an overestimate. As Moses \& Bonem (2001) pointed out, given the tendency of the species to aggregate, estimates of density using this method can reach $>10$ ind. $/ \mathrm{m}^{2}$ in one sampling unit, while surrounding abundances may be close to zero. Results from all other shallow reef sites in the north coast of Havana surveyed by Alcolado et al. (unpublished data) using a different sampling method $(10 \times 1 \mathrm{~m}$ transects) support this idea, since urchin densities (even being among the highest of the study, up to $0.77 \mathrm{ind} . / \mathrm{m}^{2}$ ) were one order of magnitude lower than Playa Franceses's abundance and are into conformity with population pattern observed at shallow reefs studied by those authors around Cuba. Thus, population densities from Playa Franceses's should be resurveyed in order to provide a better estimate of current population status.

Although our results can not explain the relative importance of mechanisms affecting abundance patterns of $D$. antillarum populations in Jardines de la Reina; observed differences in mean densities seem to be the result of local factors regulating recruitment processes rather than those responsible for inadequate larval supply or post-settlement mortality. The higher abundance of Diadema at RW and RC zones may be explained by the numerical contribution (to the overall density) of local densities from sites BG, LP and BP which are located on the west margins of major channels between keys (Pasa de Boca de Guano, Pasa de Caballones and Pasa de Boca de Piedra respectively). These sites are under the influence of a higher water flow generated by tide-driven currents circulating through those important channels and hence they might be exposed to a major larval supply when larvae are transported in the water column to the inner and outer waters of the platform as a result of diurnal tide cycles. Furthermore, the pattern of prevailing surface current in the archipelago is from east to west (González de Zayas et al. 2006). Thus, this water circulation pattern acting synergistically with tide-driven processes 
could produce a major larval retention at the west margins of those channels, enhancing urchin recruitment at reefs mentioned above. In addition, the apparently higher abundance of Diadema (author's observations) in the margins of small channels that locally bisect reef crests, reinforce that discussed above and seems to be determined by the same processes acting in a shorter spatial scale. Results from shallow reefs of Curaçao also support our findings since more abundant populations of $D$. antillarum occurred at the entrance of coastal lagoon as reported by Debrot \& Nagelkerken (2006). Future research should be addressed to determine rates of recruitment as well as variations in the abundance and size structure of Diadema among different zones within the reef crest and between both the west and the east sides of channels between keys. Although PE (site with the highest mean density) receives no influence of major channels, it is close to a communicating channel that allows a substantial water exchange between the Gulf of Ana María and the adjacent Caribbean Sea; thus the explanation discussed above is also applicable to this site.

Availability of refuges is one factor that can potentially influence on $D$. antillarum populations; since more rugose reefs can support higher urchin populations by providing shelters from predation, differences in habitat structural complexity could lead to differences in numbers of Diadema (Haley \& Solandt 2001). In addition, the biomass and structure of sea urchins assemblages is greatly dependent on three-dimensional structure of the habitat (Lee 2006). However, it is unlikely that sheltering represents a limited resource at the reef crests surveyed in June 2004 because rugosity not only was similar among studied zones in June 2004 (present study) but also among the same sites and zones analyzed by Pina-Amargós et al. (2008) in April 2005, September, 2005 and December 2005 using the semi-quantitative scale. Furthermore, considering that the power of Pearson's correlation test, performed to analyze the association between mean values of rugosity and mean population densities of Diadema, was acceptably high (Power $=0.81$ ), the lack of significance in such association obtained from the test, support the idea that sheltering is not a limited resource, at least at the reef crests surveyed in June 2004. However, more detailed studies (with more replicate samples) should be conducted toward analyzing the influence of habitat structural complexity on Diadema population density in order to improve understanding of distribution patterns at a greater spatial scale.

Although juvenile $D$. antillarum could be competitively excluded by adult $E$. lucunter and E. viridis (Shulman 1990), Diadema recruitment could be facilitated by the presence of $E$. lucunter as their mean densities were positively correlated. Given the propensity of Diadema larvae to settle in areas cleared of filamentous algae (Bak 1985), grazing activity of E. lucunter and its consequent benefit to Diadema recruitment, might be more important than possible competitive exclusion in postsettlement stages of small juvenile Diadema at the reefs crests of Jardines de la Reina. Because correlations do not prove causality, long term experimental studies considering recruitment should be carried out in the future to corroborate our findings. However, the pattern we found was consistent with that obtained by Lessios $(1988,1995)$ in the echinoid exclusion and inclusion experiments performed in the San Blas Archipelago, Panamá. Due to the absence of $T$. ventricosus in surveyed reefs during this study, no facilitation by this species has influenced the recruitment of Diadema, as has been suggested in Jamaica by Aronson \& Precht (2000) and Haley \& Solandt (2001).

Since abundances of $D$. antillarum were relatively high at several reef crests in Jardines de la Reina, low densities observed at NRW zone might be unrelated to low numbers of larvae in the water column. Inadequate larval supply due to poor fertilization success caused by low densities of upstream reproducing adults (the Alle effect) has been reported as the most likely explanation for the lack of recruitment of Diadema in the Caribbean (Lessios 1988, 1995, 2005, Hughes 1994, Edmunds \& Carpenter 
2001, Miller et al. 2003) but considering abundances from $\mathbf{R W}$ and $\mathbf{R C}$ zones, it could be agreed that upstream populations have reached such levels of population density that they are able to produce enough larvae to overcome mortality in the planktonic stage and therefore an adequate larval supply to sustain recruitment at surveyed reefs. Thus, Diadema populations from NRW zone seem to be limited, in part, by oceanographic features of the reefs in question and could be conditioned by the presence of $E$. lucunter that might provide suitable substrata for larval settlement as discussed above. However, the size frequency distribution of D. antillarum at this zone indicates successful recruitment and that in spite of low densities, juvenile Diadema persist along time.

Mean test sizes showed the same pattern of variation as mean densities of $D$. antillarum across zones, being higher within the marine reserve where abundances reached the maximum values. These results are consistent with the positive relationship found between size and density across sites at the present study. Contrary to our finding, an inverse relationship between size and density has been well documented for the species by Carpenter (1981) and Levitan $(1988,1989,1991)$ who pointed out the ability of Diadema to reduce body size when density increases and therefore food is limited. Considering abundance patterns and size frequency distributions, the association we found appear to be the result of a recent recruitment event at reefs from NRW zone as suggested by the high proportion of urchins with sizes $\leq 40$ mm encountered in that zone (Fig. 4).

Given that growth rate of $D$. antillarum slows down as the test diameter increase (Ogden \& Carpenter 1987), estimation of age in adult sea urchins, could lead to inaccurate results, even when food is not limited. However, the size frequency distribution pooled across all sites, in association with the fact that the maximum test diameter of the species has not been attained (about 100mm; Ogden \& Carpenter 1987), indicates that recruitment of $D$. antillarum populations in Jardines de la Reina began to be noticeable few years $(\approx 3$ years) before the survey took place, suggesting that Diadema was depleted in the past and population is recovering now.

Because of the lack of scientific information about abundances of $D$. antillarum in Jardines de la Reina before 2001 [data reported by Alcolado et al. (unpublished data)] and the complete lack of information about size structure before the present study it is impossible to arrive to more detailed conclusions about its population dynamics. Nevertheless, our study shows that environmental conditions across the best conserved of the four archipelagos around Cuba, one of the best conserved and also the largest marine reserve in the Caribbean, appear to enhance larval recruitment and survival in post-settlement stages of $D$. antillarum, suggesting that recovery is undergoing in Jardines de la Reina and that if a sustained increase in population densities occurs, the patterns we found and those from other particular reefs around Cuba could become in a country wide recovery of the species, contributing to the wider Caribbean population.

\section{ACKNOWLEDGMENTS}

The authors are thankful to the staff of Azulmar for logistical support on Jardines de la Reina, especially to Giuseppe Omegna (Pepe) its manager and Noel López. To WWF Canada for funding this research and to E. Sala, Director of the Center for Marine Biodiversity and Conservation of the Scripps Institution of Oceanography, for funding and logistics. We thank the Ministry of Science, Technology and Environment for funds and logistics, especially C. Pazos Alberdi, R. Gómez Fernández, A. Zúñiga Ríos. Infinite thanks to CIEC's staff for supporting us in doing research on Jardines de la Reina, specially to L. Hernández Fernández, A. Zayas Fernández, W. Acosta de la Red, A. Jiménez del Castillo, M. Lazarte Llanes and V.O. Rodríguez Cárdenas. We also want to thanks P.M. Alcolado, H.P. Caballero, Y. Lezcano, R. del Valle, H.A. Lessios, M. Chiappone and R.J. Miller for assistance in bibliography and especial considerations. 


\section{RESUMEN}

La mortalidad de Diadema antillarum en 1983-1984 afectó más del 93\% de la población del Caribe. Aunque no existen datos publicados sobre el estado de sus poblaciones en arrecifes cubanos antes y después de la mortalidad, se conoce anecdóticamente que fueron afectadas. En el presente trabajo se analizan las variaciones espaciales de la abundancia y estructura de tallas de $D$. antillarum en 22 arrecifes frontales en Jardines de la Reina, para lo cual se realizaron cinco recorridos de $30 \times 2 \mathrm{~m}$ en cada sitio entre Junio de 2004 y Septiembre de 2005. Las densidades de Diadema fueron mayores en las crestas arrecifales $\left(0.08-2.18 \mathrm{ind} . / \mathrm{m}^{2}\right)$ mientras que en las pendientes fueron hasta tres órdenes de magnitud menor y la densidad máxima fue 0.13 ind. $/ \mathrm{m}^{2}$. Las crestas con mayor abundancia de Diadema están ubicadas en los márgenes de las grandes pasas existentes entre cayos donde el reclutamiento parece estar favorecido por las condiciones oceanográficas locales y facilitado por la abundancia de Echinometra lucunter. La distribución de frecuencia de tallas de Diadema sugiere que el reclutamiento comenzó a ser notable aproximadamente tres años antes del muestreo, indicando que en el pasado sus poblaciones estuvieron afectadas y ahora están recuperándose.

Palabras clave: Diadema antillarum, recuperación de erizos marinos, densidad poblacional, estructura de tallas, Jardines de la Reina, Cuba.

\section{REFERENCES}

Appeldoorn, R.C. \& K.C. Lindeman. 2003. A Caribbeanwide survey of marine reserves: spatial coverage and attributes of effectiveness. Gulf. Caribb. Res. 14: 139-154.

Alvarado, J.J., J. Cortés \& E. Salas. 2004. Population densities of Diadema antillarum Philippi at Cahuita National Park (1977-2003), Costa Rica. Caribb. J. Sci. 40: 257-259.

Aronson, R.B. \& W.F. Precht. 2000. Herbivory and algal dynamics on the coral reef at Discovery Bay, Jamaica. Limnol. Oceanogr. 45: 251-255.

Back, R.P.M. 1985. Recruitment patterns and mass mortalities in the sea urchin Diadema antillarum. Proc. $5^{\text {th }}$ Int. Coral Reef Congress 5: 267-272.

Caballero, H.P., D. Rosales \& A. Alcalá. 2006. Estudio diagnóstico del arrecife coralino del Rincón de Guanabo, Ciudad de la Habana, Cuba.1. Corales, esponjas y gorgonáceos. Rev. Invest. Mar. 27: 49-59.

Carpenter, R.C. 1981. Grazing by Diadema antillarum Philippi and its effects on the benthic algal community. J. Mar. Res. 39: 747-765.
Carpenter, R.C. \& P.J. Edmunds. 2006. Local and regional scale recovery of Diadema promotes recruitment of scleractinian corals. Ecol. Lett. 9: 271-280.

Chiappone, M., D.W. Swanson \& S.L. Miller. 2002. Density, spatial distribution and size structure of sea urchins in Florida Keys coral reef and hard-bottom habitats. Mar. Ecol. Prog. Ser. 235: 117-126.

Debrot, A.O. \& I. Nagelkerken. 2006. Recovery of the long-spined sea urchin Diadema antillarum in Curaçao (Netherlands Antilles) linked to lagoonal and wave sheltered shallow rocky habitats. Bull. Mar. Sci. 79: 415-424.

Edmunds, P.J. \& R.C. Carpenter. 2001. Recovery of Diadema antillarum reduces macroalgal cover and increases abundance of juvenile corals on a Caribbean reef. Proc. Natl. Acad. Sci. 98: 5057-5071.

Fonseca, A.C., E. Salas \& J. Cortés. 2006. Monitoreo del arrecife coralino Meager Shoal, Parque Nacional Cahuita, Costa Rica (sitio CARICOMP). Rev. Biol. Trop. 54: 755-763.

Guardia, E., A.P. Valdivia \& P. González-Díaz. 2004a. Estructura de las comunidades bentónicas en la zona de buceo de María La Gorda, Ensenada de Corrientes, Sureste de la Península de Guanahacabibes, Cuba. Rev. Invest. Mar. 25: 103-111.

Guardia, E., P. González-Díaz \& S. Castellanos-Iglesias. 2004b. Estructura de la comunidad de grupos bentónicos sésiles en la zona de buceo de Punta Francés, Cuba Rev. Invest. Mar. 25: 81-90.

Guardia, E., P. González-Díaz, A. Valdivia \& O.O. González. 2006. Estructura y salud de la comunidad de corales en el arrecife de la zona de buceo de Cayo Levisa, Archipiélago Los Colorados, Cuba Rev. Invest. Mar. 27: 197-208.

González de Zayas, R., A. Zúñiga-Ríos, O. Camejo-Cardoso, L.M. Batista-Tamayo \& R. Cárdenas-Murillo. 2006. Atributos físicos del ecosistema Jardines de la Reina, p. 296-351. In: F. Pina-Amargós. Ecosistemas costeros: biodiversidad y gestión de los recursos naturales. Compilación por el XV Aniversario del Centro de Investigaciones de Ecosistemas Costeros (CIEC). CUJAE, Ciudad de la Habana, Cuba.

Haley, M.P. \& J.L. Solandt. 2001. Population fluctuations of the sea urchins Diadema antillarum and Tripneustes ventricosus at Discovery Bay, Jamaica: a case of biological succession? Caribb. J. Sci. 37: 239-245.

Herrera-Moreno, A., E. Valdés-Muñoz \& D. Ibarzábal. 1981. Evaluación poblacional del erizo negro, Diadema antillarum Phillipi, mediante un diseño de muestreo aleatorio estratificado, y algunos aspectos de su biología. Ciencias Biológicas 6: 61-79. 
Hughes, T.P. 1994. Catastrophes, phase shifts and largescale degradation of a Caribbean coral reef. Science 265: $1547-1551$.

Hughes, T.P., B.D. Keller, J.B.C. Jackson \& M.J. Boyle. 1985. Mass mortality of the echinoid Diadema antillarum Philippi in Jamaica. Bull. Mar. Sci. 36: 377-384.

Hunte, W. \& D. Younglao. 1988. Recruitment and population recovery in the black sea urchin Diadema antillarum in Barbados. Mar. Ecol. Prog. Ser. 45: 109-119.

Jordán-Garza, A.G., R.E. Rodríguez-Martínez, M.A. Maldonado \& D.M. Baker. 2008. High abundance of Diadema antillarum on a Mexican reef. Coral Reefs 27: 295.

Lee, S.C. 2006. Habitat complexity and consumer-mediated positive feedbacks on a Caribbean coral reef. Oikos 112: 442-447.

Lessios, H.A. 1988. Population dynamics of Diadema antillarum (Echinodermata: Echinoidea) following mass mortality in Panama. Mar. Biol. 99: 515-526.

Lessios, H.A. 1995. Diadema antillarum 10 years after mass mortality: still rare, despite help from a competitor. Proc. R. Soc. Lond. B. 259: 331-337.

Lessios, H.A. 2005. Diadema antillarum populations in Panama twenty years following mass mortality. Coral Reefs 24: 125-127.

Lessios, H.A., D.R. Robertson \& J.D. Cubit. 1984. Spread of Diadema mass mortality through the Caribbean. Science 226: 335-337.

Levitan, D.R. 1988. Density-dependent size regulation and negative growth in the sea urchin Diadema antillarum Philippi. Oecologia 76: 627-629.

Levitan, D.R. 1989. Density-dependent size regulation in Diadema antillarum: effects on fecundity and survivorship. Ecology 70: 1414-1424.

Levitan, D.R. 1991. Skeletal changes in the test and jaws of the sea urchin Diadema antillarum in response to food limitation. Mar. Biol. 111: 431-435.

Liddell, W.D. \& S.L. Ohlhorst. 1986. Changes in benthic community composition following the mass mortality of Diadema at Jamaica. J. Exp. Mar. Biol. Ecol. 95: 271-278.

Macintyre, I.G., P.W. Glynn \& F. Hinds. 2005. Evidence of the role of Diadema antillarum in the promotion of coral settlement and survivorship. Coral Reefs 24: 273.
Miller, J.R., A.J. Adams, N.B. Ogden, J.C. Ogden \& J.P. Ebersole. 2003. Diadema antillarum 17 years after mass mortality: is recovery beginning on St. Croix? Coral Reefs 22: 181-187.

Moses, C.S. \& R.M. Bonem. 2001. Recent population dynamics of Diadema antillarum and Tripneustes ventricosus along the north coast of Jamaica, W. I. Bull. Mar. Sci. 68:327-336.

Myhre, S. \& A. Acevedo-Gutiérrez. 2007. Recovery of sea urchin Diadema antillarum populations is correlated to increased coral and reduced macroalgal cover. Mar. Ecol. Prog. Ser. 329: 205-210.

Noriega, N., S.M. Pauls \& C. del Mónaco. 2006. Abundancia de Diadema antillarum (Echinodermata: Echinoidea) en las costas de Venezuela. Rev. Biol. Trop. 54: 793-802.

Ogden, J.C. \& R.C. Carpenter. 1987. Species profiles: life histories and environmental requirements of coastal fishes and invertebrates (south Florida) Long spined black sea urchin. U.S. Fish Wildl. Serv. Biol. Rep. 82. U.S. Army Corps of Engineers, TR EL-82-4. 17 p.

Pina-Amargós, F. 2008. Efectividad de la Reserva Marina de Jardines de la Reina en la conservación de la ictiofauna. Tesis de Doctorado, Universidad de La Habana, La Habana, Cuba.

Pina-Amargós, F., L. Hernández-Fernández, L. CleroAlonso \& G. González-Sansón. 2008. Características de los hábitats coralinos en Jardines de la Reina, Cuba. Rev. Invest. Mar. 29: 225-237.

Randall, J.E., R.E. Schroeder \& W.A. Starck. 1964. Notes on the biology of the echinoid Diadema antillarum. Caribb. J. Sci. 4: 421-433.

Shulman, M.J. 1990. Aggression among sea urchins on Caribbean coral reefs. J. Exp. Mar. Biol. Ecol. 140: 197-207.

Steiner, S.C.C. \& S.M. Williams. 2006. The density and size distribution of Diadema antillarum in Dominica (Lesser Antilles): 2001-2004. Mar. Biol. 149: 10711078 .

Weil, E., J.L. Torres \& M. Ashton. 2005. Population characteristics of the sea urchin Diadema antillarum in La Parguera, Puerto Rico, 17 years after the mass mortality event. Rev. Biol. Trop. 53: 219-231.

Williams, I.D. \& N.V.C. Polunin. 2001. Large-scale associations between macroalgal cover and grazer biomass on mid-depth reefs in the Caribbean. Coral Reefs 19: 358-366. 